Article

\title{
Hope, Disillusion and Coincidence in Migratory Decisions by Senegalese Migrants in Brazil
}

\author{
Philipp Roman Jung \\ Institute of Geography and Spatial Planning, Universidade de Lisboa, 1600-276 Lisbon, Portugal; \\ E-Mail: pjung@campus.ul.pt
}

Submitted: 4 October 2020 | Accepted: 10 December 2020 | Published: 25 March 2021

\begin{abstract}
Uncertainty is an essential characteristic of our lives. However, by moving from one country to another, from a familiar context to an unfamiliar one, uncertainty becomes a key element of migrants' decisions. In times of restricted mobility regimes, migrants often do not know if they will be able to reach the desired destination. Even if they manage to do so, it is still uncertain if they will be able to fulfil their aspirations. However, uncertainty also leaves room for hope. Departing from the conceptualisation of hope as the simultaneity of both potentiality and uncertainty and from the concept of circumstantial migration, this article analyses (1) retrospectively the decision of Senegalese migrants to move to Brazil and (2) the intentions of onward migration. Based on empirical data collected through ethnographic fieldwork in four Brazilian cities, this article shows how migration as a form of social hope is redirected to new destinations and that this redirection is a consequence of circumstances and coincidences, which enable or prevent movement. Potential positive outcomes of migration outweighed negative ones, which play a minor role and hardly affect decisions to leave Senegal. However, decisions to emigrate are often based on incomplete information and ill-informed expectations regarding the circumstances at the destination and can lead to feelings of disillusion. The impact of uncertainties shows a more differentiated picture in the context of onward migration intentions. While some migrants are willing to take big risks in onward migration, others try to minimize uncertainties.
\end{abstract}

\section{Keywords}

Brazil; hope; uncertainty; Senegalese migrations; south-south migration

\section{Issue}

This article is part of the issue "Decision-Making under Uncertainty: African Migrants in the Spotlight" edited by Didier Ruedin (University of the Witwatersrand, South Africa / University of Neuchâtel, Switzerland).

(C) 2021 by the author; licensee Cogitatio (Lisbon, Portugal). This article is licensed under a Creative Commons Attribution 4.0 International License (CC BY).

\section{Introduction}

Hope is without a doubt an essential feature of migration decision-making, a "crucial dynamic motivating migration processes" (Mar, 2005, p. 364). Prospective migrants hope, for instance, for a better life, financial or professional success, or safety. Migratory aspirations in its multiple forms would hardly turn into actual movement without the existence of hope that one will be able to achieve them. However, hope, as an anticipation of the 'not yet' (Bloch, 1986), also implies that the fulfilment of these aspirations is uncertain. Failure and disappointment are possible outcomes. While uncertainty is in some form or another a part of our lives, it becomes a central element of our decisions and activities when we exchange a familiar context for an unfamiliar one, for example, the movement from one's home country to an overseas destination. Aspiring migrants do not know if their migratory project will be successful and if, one day, they will come back to their country of origin as a prosperous returnee. Moreover, as a consequence of restrictive migration policies and control, migrant journeys often include high risks and have become increasingly longer in time and space, turbulent and dangerous (Schapendonk, 2012; Vammen, 2019). Migrants cannot be certain that they will be able to reach their desired destination and which conditions they will encounter during their journey. 
Despite these uncertainties and the enormous obstacles that (aspiring) migrants must face, migration is not only seen as a possibility, but often as a necessity for many citizens in West Africa (Graw \& Schielke, 2012). In other words, the hope to achieve a better life through migration remains strong throughout the region. Three aspects are crucial in this context. First, in many West African countries crises and uncertainties are experienced as a constant condition (Vigh, 2008). Thus, uncertainties and risks at places of departure need to be considered for the understanding of risk-taking behaviour (Alpes, 2012). Secondly, throughout the region and especially in countries with a strong migration culture like Senegal, international mobility has become a synonym for social mobility (Graw \& Schielke, 2012). Finally, due to mass media, returning migrants, transnational spaces, and the presence of goods from the global market, the 'global world' is increasingly a constitutive element of people's everyday world (Graw \& Schielke, 2012; Kleist, 2017). People's expectations and imagination of a 'good life' are shaped by these global flows, but globalization is often experienced as absence (Graw, 2012). A better life or opportunities structures to obtain such a life are, therefore, often imagined and sought elsewhere. Migration becomes a central element of social hope.

While hope is a driving force of migration aspirations, actual mobility behaviour is eventually determined by the ability to move (Alpes, 2012; Carling, 2002). Restrictive immigration policies and migration control increasingly hinder the ability of West Africans to move internationally, above all to the most desired destinations in Europe and North America. In the context of restrictions and simultaneous widespread aspirations to emigrate, migration opportunities are a scarce and much desired event. This scarcity affects the way decisions are made and how destinations are chosen. A person needs to grasp an opportunity when it emerges. These opportunities can channel movements in direction that do not head, at least not directly, to an aspired destination. They often emerge suddenly, resulting from network contacts, information flows and processes of mediation and can trigger unplanned departures (Alpes, 2012; Carling \& Haugen, 2020; de Boeck, 2012). However, sudden departures and the necessity and willingness to grasp opportunities may also increase risks and uncertainties of migrations since migrants may take decisions without much information about the conditions and opportunities structures at the destination. This may lead to feelings of disillusion and desires for renewed movements.

This article discusses questions of hope, ability, uncertainty, disillusion and coincidence in the context of mobility decisions by Senegalese migrants in Brazil. These questions are analysed retrospectively regarding the decision to emigrate from Senegal as well as in the context of onward migration intentions and aspirations in Brazil. For this purpose, I adopt the framework of hope analysis proposed by Kleist (2017) and combine it with Carling and Haugen's (2020) concept of 'circumstantial migration.' Hereby I seek to demonstrate that in times of restrictive 'mobility regimes' (Glick Schiller \& Salazar, 2013), hope in migration is redirected to new destinations, in this case Brazil, and that this redirection is a result of processes of mediation and the emergence of opportunities. I will show that decisions to migrate to Brazil are driven by the hope to improve one's socioeconomic situation and here potential positive outcomes of migration outweighed negative ones. Therefore, uncertainties play a minor role and hardly affect emigration decisions in Senegal. However, the assessment of uncertainties shows a more differentiated picture in the context of onward migration intentions. This difference is connected to spatialized or temporalized forms of hope and feelings of disillusion, but also show the possible impact of migratory experiences and knowledge on risktaking strategies. The article seeks to contribute to the growing body of literature on hope in migration, the development of interregional south-south migration and onward migration processes.

The presented empirical data results from an ethnographic research conducted with Senegalese migrants in Brazil between 2017 and 2019. During four periods of fieldwork, each lasting from two to four months, I collected data through biographical and problem-centred interviews, informal conversations, and direct and participatory observation. Research sites were in the city of São Paulo and in Praia Grande, a coastal town which is located about $80 \mathrm{~km}$ east of the metropolis, and in the two medium-sized cities of Caxias do Sul and Passo Fundo, which are important industrial and agricultural sites in Brazil's most southern state, Rio Grande do Sul. The four cities were chosen due to their importance in Senegalese immigration in Brazil. São Paulo, Caxias do Sul and Passo Fundo have relatively big Senegalese communities but are also important for other forms of mobility and circulation of Senegalese within the country. During the Brazilian summer months Senegalese street hawkers move temporary to Praia Grande and sell their products at the local beaches. In total, I conducted 25 interviews with 21 migrants. Additionally, a migration history chart (Carling, 2012) was elaborated together with 16 of the interviewees. All interviews and conversations were held in Portuguese or French. Interview quotes used in this article were translated to English. The names used in this article are pseudonyms.

\section{Hope, Uncertainty and Coincidence in Migration: An Analytical Framework}

In recent years, a growing number of scholarly accounts have called for the consideration of hope as an essential feature of migrants' decision-making. Vammen (2017, p. 40) argues that "hope as an analytical lens for migrant mobility, can capture phenomenological aspects of how imaginaries frame and affect livelihood strategies, mobility, and notion of the future." Kleist (2017) proposes a framework for the analysis of hope in migration based 
on four dimensions: (1) The distinction between societal and social hope; (2) the different repositories of hope; (3) the temporal and spatial horizons of different modes of hope; and (4) the relationship between existential and physical (im)mobility. The four dimensions are interrelated and will be shortly presented below.

Hope describes an anticipatory expectation, a desire for "something better" (Mar, 2005, p. 364) and is characterized by the simultaneity of potentiality and uncertainty of the future. It is a social and collective phenomenon that is embedded in and inspired by social imaginaries and realities. Hage (2003) calls the perception of a better future within a particular society 'social hope.' In many West African countries, crises and uncertainty are experienced as a constant condition and this effects negatively the hope to live a meaningful and dignified social life within the society. 'Societal hope' (Hage, 2003), e.g., the confidence in the capacity or even the willingness of the state to provide the conditions for its citizens to achieve a better life, to experience social mobility within society, is a rare phenomenon in this context. Lubkemann (2017) argues that under conditions of social exclusion, hope relies above all on spatialization rather than on temporalization, as in the case of seeking the improvement of life conditions and social status with time through education or hard work. In Senegal, international mobility has become almost a synonym for social mobility and a ritual for the transition to adulthood (Mbodji, 2008; Prothmann, 2018). It represents a spatialized strategy for constituting social hope. Thus, migration is understood as a means to overcome existential immobility, to escape social death (Vigh, 2009). Repositories of hope are the sources of knowledge, institutions and forces that are perceived as brokering or facilitating social hope (Kleist, 2017). With regards to migration these repositories can be, for instance, actors of the migration industry or social networks that may help one to overcome international mobility barriers, issue documents or provide information about opportunities at the destination.

Hope as an analytical framework is especially useful to understand migration decisions in times of restrictive mobility regimes and increasing risks and uncertainties. According to Williams and Baláž (2012) uncertainty is the result of two different factors: imperfect knowledge and the unpredictability of the future. While the latter cannot be influenced by aspiring migrants, they can try to improve the former by obtaining information about obstacles at the route or conditions at the destination. Information about opportunities structures, immigration legislation, border controls, etc., can reduce risks and uncertainties with regards to migratory movements and are often transmitted through migrant networks that hereby impact migration decisions (Haug, 2008; Snel, Engbersen, \& Faber, 2016). However, the information may also be selective and one-sided. Since migration is often connected to high expectations and social status, migrants may not tell their relatives and friends at home about the difficulties they experience abroad. It was for long assumed that migration decision-making is based on the possession of information about labour market conditions, for instance wages and employment opportunities, at the destination. Most prominent proponents of this line of thought are neoclassical theories like the microeconomic model of individual choice, according to which prospective migrants compare wages and employment opportunities at the destination and place of origin, and under the consideration of costs of movement measure the expected net returns of a migration (e.g., Harris \& Todaro, 1970). Migrants would be expected to choose their destination on account of the expected highest net returns. However, neither are migration decisions solely economic (Halfacree, 2004), nor are prospective migrants in possession of all-encompassing information about the conditions elsewhere.

Salazar (2011, p. 586) writes that "imaginaries play a predominant role in envisioning both the green pastures and the (often mythologized) memory of the homeland." Distant places are a constant element of people's life worlds all around the globe, from a global city like New York to a small town in the Senegal river valley. Images about other places are transmitted globally through a variety of channels, and besides the stories of (returned) migrants, mass media is crucial for the construction of imaginaries (Appadurai, 1996). However, these images do not necessarily represent the reality, in contrary they are often misrepresentations. Though they transmit some sort of information, they may lead to illusions of the life and opportunities structures at another place. Migrants expectations may not be matched after arriving at the destination, resulting in disillusion, "the feeling of disappointment resulting from the discovery that something is not as good as one believed it would be" (Belghazi \& Moudden, 2016, p. 41). Nevertheless, migrants should not be conceptualized as uniformed adventures, who would not have moved if they would have been better informed. In some form or another, prospective migrants have some idea about what to expect during the migration journey. They are aware of the risks of migration and of unsuccessful attempts (Alpes, 2012; Fiedler, 2020). But failed attempts are often attributed to bad luck or lack of effort, which are often interrelated in the discourses of both prospective and actual migrants. As Hernández-Carretero (2017) shows, luck or chance must be actively pursued. In Islamic societies luck is connected to destiny and although "fate is conceived as a predetermined set of events decreed by God..., individuals are expected to play an active role in fulfilling their destiny by scouting out the routes to what has been allotted to them in this world" (Gaibazzi, 2015, p. 228). Hope related to fate and luck may explain the disposition to take risks and face uncertainties of migration. Migrants take their chances in the anticipation that the outcome will be positive (Hernández-Carretero, 2017, p. 116). Moreover, uncertainties and risks at places of departure need to be considered in order to understand the risk-taking behaviour of migrants (Alpes, 2012), or in 
the words of Vigh (2009, p. 105): "The escape from social death entails risking one's physical existence."

Recent studies have also shown that in many cases migration decisions are rather determined by opportunities of movement than by the possession of information, highlighting both the role of mediation and coincidence for migration decisions and trajectories (Carling \& Haugen, 2020; Alpes, 2012, 2017). Carling and Haugen (2020, p. 2) suggest the concept of circumstantial migration to describe the unpredictable ways in which migration trajectories and experiences unfold under the influence of coincidence and micro-level context. Coincidental factors that act at the micro-level include chance encounters with others, good or bad luck at critical junctures, and accidental discovery of opportunities. The authors argue that the consideration and analysis of coincidence and micro-level context allows us to understand "twist and turns as constitutive elements of many migration experiences," i.e., the non-linearity of migration, as well as the "prominent role circumstances play under certain migration regimes" (Carling \& Haugen, 2020 , p. 3). Moreover, it allows to examine the interrelation between plans and serendipities. The necessity, but also the willingness, to grasp an opportunity to migrate when it arises is one of the consequences of restrictive mobility regimes. The concept of circumstantial migration can be a fruitful addition to the analysis of hope as it allows to examine how hope is created or lost in specific situations and under specific circumstances.

\section{Senegalese Migrations to Brazil: A Recent Phenomenon}

Senegalese immigration in Brazil is a recent phenomenon and cannot be understood without putting it in the global context. Although a limited number of Senegalese citizens, mostly students, arrived in Brazil during the 1990s and early 2000s, it was only around 2008 that the South American country started to attract a growing number of Senegalese migrants. This growth occurred at a time when much of the world was suffering from the consequences of the 2007 financial crisis, which impacts affected Brazil only a few years later. Moreover, this period is characterized by increasing difficulties for Senegalese to migrate both 'regularly' and 'irregularly' to Europe. The securitization of European borders in the Mediterranean area and increasing patrols in West African waters, together with a growing number of bilateral and multilateral agreements between the European Union or individual member states and countries in North and West Africa, hinder movements via the Canary Islands and North Africa (Adepoju, Van Noorloos, \& Zoomers, 2009; Vives, 2017). At the same time restrictive immigration policies in Europe made a regular entry almost impossible (Finotelli \& Sciortino, 2013).

Parallel to these developments, Brazil experienced an average economic growth of $4 \%$ between 2000 and 2011 and the economic and political coopera- tion between Brazil and a variety of African countries increased (BRASIL, 2010). Moreover, through its role as a member of the BRICS and the realization of major global events such as the 2014 World Cup and the 2016 Olympic Games, the country became more visible on the global stage. These developments contributed for Brazil to emerge as a destination for African, Asian, and Caribbean migrants. Furthermore, Senegalese movements to Brazil are connected to regional developments in South America. Until November 2015, Ecuador's open-door policy (Freier \& Holloway, 2018) allowed Senegalese migrants to enter without any visa regulations and put a foot on South American soil. Brazil was also a transit country for Senegalese migrants on their way to Argentina, a movement which started in the end of the 1990s (Minvielle, 2015; Vammen, 2019). Finally, the country is both the origin and destination for multinational migrations, which are an important factor for the development of Senegalese migratory movements to Brazil. In short, it was the interplay of factors on a global, regional and national level that contributed to Senegalese migration to Brazil. However, the argument that the difficulties of migrating to the 'Global North' are co-responsible for the emergence of Brazil in intercontinental south-south migrations may mislead to the assumption that Senegalese migrants can move freely to and within the region. It neglects the fact that immigration policies in Brazil, but also in other countries in the region, hinder the arrival of migrants from Senegal. The increasing difficulties for Senegalese migrants to obtain a visa at the Brazilian embassy in Dakar prevent them from moving directly to the country and often result in long and dangerous trajectories, whose risks and uncertainties increasingly reflect the struggles that migrants face in other regions (Vammen, 2019).

Although we do not know the exact figures of the entry of Senegalese migrants into Brazilian territory, the available data suggests a significant increase between 2012 and 2015. In total 8.486 Senegalese migrants applied for asylum between 2010 and 2018 (BRASIL, 2020). However, the likelihood of Senegalese migrants to earn asylum is very small. Only 14 out of 5.281 requests were granted until May 2017 (personal communication, Diego Nepomuceno Nardi, UNHCR Brazil, 9 May 2017, Brasília). Nevertheless, most Senegalese migrants use this process to get the temporary permission to stay and work in Brazil and later try to get a residence permit through other procedures. Furthermore, the Brazilian government decided in November 2019 to allow Senegalese migrants with an open asylum request to apply for a residence permit through a special procedure (BRASIL, 2019). The actual number of Senegalese migrants in the country is difficult to estimate. Asylum requests allow to estimate the number of arrivals of Senegalese migrants in Brazil since 2010 and deduce an increase of Senegalese immigration during this period. But we do not know if they still reside in the country. Moreover, undocumented migrants are not included in 
the statistics. Until 2015-2016 there was a high demand for Senegalese migrants' labour force in southern Brazil, especially in the slaughter and cold storage sector, and in construction and gastronomy, but the following economic crisis forced many Senegalese in the informal sectors, where they work above all as street hawkers and often suffer repressions by police and supervision officers. The devaluation of the Brazilian Real further negatively impacted the capacity of Senegalese migrants to support their families at home. The economic crisis may have also prompted Senegalese migrants to leave Brazil.

\section{Brazil as a Destination: Opportunity, Hope and Disillusion}

Migration is an open-ended, often non-linear process and cannot be understood solely as the movement from one country to another. Migrants aspire to achieve something by moving and not just to move. Hernández-Carretero (2017) argues that emigration and return should be understood as stages in the same project of socioeconomic prosperity. This idea can be extended to onward migration, which are further stages of the same project. In this sense, the use of words like 'origin,' 'transit,' and 'destination' refers to spatial movement, a specific journey done by the migrant, not to a life project. As was shown above, the integration of Brazil in the horizon of Senegalese migrants is directly connected to developments regarding Senegalese migration in other countries and regions. Migration decision-making need to be examined in consideration of these interrelations. In this context, it is especially the ability to move to Brazil which strongly influenced the choice of the country as a destination or a potential stepping-stone for further movements. Abdou, a 24-year-old man from Casamance, who arrived in Brazil in 2015, after taking the long route via Ecuador and Peru, explains why he chose Brazil:

I actually wanted to go to Italy. I applied for a visa for Italy, but it did not work.....We learned about Brazil [at school] in Casamance, but I never imagined that I would go there one day. The first place I had in my head was Italy.....But when it did not work, a friend told me that entering Brazil is a little easier.....। paid a guy there. He is a friend of my uncle. My uncle told him that he has a nephew who wants to travel and tried to go to Italy, but it did not work, and who wants to leave in any case. He said to my uncle: I know a guy. If he wants to go to Brazil, they will do the visa for him. You will get a visa. I did not know that there was no visa for Brazil. Only later he told me that I have to go to Ecuador. He arranged the journey for me. (Abdou, April 2019)

Although Abdou did not have friends or relatives in Brazil and no accounts of Senegalese migrants living in Brazil, he decided to seek a better life by moving there.
For Abdou, the achievement of a better future was connected to spatial movement and Brazil was considered as an alternative to Italy. He redirected his social hope in form of migration to another country. A few of my interviewees stated that they applied first for a visa for a European country or the USA, but their requests were denied. Others desisted from migrating there, due to the expected difficulties of getting legal papers or the expected risks of irregular migration routes. Brazil, but also Argentina and Cape Verde, from where migrants later moved to Brazil, were regarded as alternatives for emigration from Senegal. The decisive factor was to be able to leave Senegal, or in the words of Elimane, a 52-year-old Senegalese man living in Caxias do Sul: "I did not choose the country that I would go to, just to get out of Senegal." Similar to descriptions by Carling and Haugen (2020) and Alpes (2012, 2017), the ability to go to Brazil is a main factor influencing its choice as a destination. While Brazil is not considered as a top country in their 'destination hierarchy' (Belloni, 2020), it still allows migrants to sustain their hope of a better future through spatial movement. The destination is here almost secondary. The open-door policy of Ecuador was central for the increase of Senegalese immigration in Brazil between 2013 and 2015. My Senegalese interlocutors, who took the route via Ecuador, Peru and sometimes Bolivia, often did not try to apply for a visa at the Brazilian embassy, but instead decided immediately to take this long journey, which often took them several weeks and costed between 3.000 and 4.500 Euros. In most cases it was the migration broker who directed their attention to Brazil. In a similar way, Minvielle (2015) describes how Senegalese emigration to Argentina increased through the mediation and facilitation work of migration brokers, who actively recruited aspiring migrants. It seems likely, that migration brokers also played an important role for the growth of migrant journeys through Ecuador to Brazil. In the context of involuntary immobility and limited opportunities to migrate, migration brokers are important repositories of hope, who allow aspiring migrants to develop or maintain hope.

Hope as a result of social imaginaries is strongly connected to information and images. All the interviewees possessed some sort of information about Brazil, and most of them received them, among others, through migrant networks. Migrants with relatives or friends who already had moved to Brazil, were often actively encouraged by them to try their luck there. Only five of my interviewees did not possess any kind of contacts in Brazil, not even in form of weak ties, prior to their journey. Their intention to move to Brazil developed either through stories about the success of Senegalese migrants and the positive development of the country or was directly influenced by migration brokers, as mentioned above. Economic opportunities, both real and imagined ones, also impacted the choice of Brazil. Personal accounts from migrants and statements by persons in Senegal describing positive developments of Brazil shaped the 
image of the country in Senegal. This image is further moulded by the media, which often either reinforce stereotypical images of drug traffic and violence or create unrealistic expectations due to the presentation of wealthiness in Brazilian telenovelas. Positive attributes were also constructed through global events in Brazil, which stimulated migration intentions. None of the migrants had arranged employment prior to the migration. Hence uncertainty with regards to economic and employment opportunities was a central aspect of their migration decision but did not negatively affect it. The potentiality of the future in Brazil was valued higher. It was much more attractive than staying in Senegal. Cheikh, 54-year-old, who already lived several years in different European countries and worked all around West Africa, describes how he had lost the hope in Senegal after losing his job:

I hoped that it would be better than staying in Senegal. I did not have any more hope there.... I lived too long outside of Senegal and therefore I had the idea that I could no longer stay in Senegal without doing anything....I never wanted to travel again, because really.... I do not know how to put it; I had lost the desire as they say. (Cheikh, March 2019)

Cheick wanted to stay in Senegal with his family but did not see any alternative to leaving Senegal again. Also, the following example of Souleymane, 58-year-old, who left Senegal for the first time in 2014 and emigrated to Brazil, demonstrates how social and societal hope impacted his migration decision and how hope lost its temporal dimension and became spatialized. Souleymane, who is originally from the region of Kaolack, was already successfully working, for several years, in the import sector for used cars in Dakar. But in 2010, the government under Abdoulaye Wade changed the law and banned the importation of cars over 5 years old in Senegal. Due to this change, Souleymane's job as intermediary became needless and after the government of Macky Sall, which was elected in 2012, did not revoke the law, he lost his hope that he would be able to support his wife and three children if he stayed in Senegal. "It was because of the system that I needed to leave Senegal," he told me. It was the absence of societal hope that pushed him, at the age of 52, to reorient and spatialize his hope. In 2014, a time when Brazil became increasingly popular as a destination, he decided to seek his luck there. His choice of Brazil was not only determined by the ability to go there, but also by a positive image of the country. He explains how the holding of the Football World Cup in 2014 shaped his image of Brazil:

Well, I chose Brazil, because at that time, in 2014, they had to organize a World Cup. I said to myself that that was an opportunity.... thought that since the country is receiving a World Cup, it must be a country that is developed, and I can make my life there....If it is not a big country, an emerging country, it cannot organize a World Cup. (Souleymane, April 2019)

However, his expectations were not met. Today he is strongly disillusioned:

When I left Senegal, I believed that I would earn money when I go out [emigrate]. But unfortunately, my dream is shattered. Unfortunately. Because Brazil, the country that I thought could bring me something, disappointed me when I arrived....It is a disappointment for me because I believed that here is the 'El Dorado.' But it is not. There are people here who are poorer than the people in Senegal. (Souleymane, April 2019)

While I conducted the interview with him in April 2019, he was in a state of hopelessness. He has lost both temporalized and spatialized forms of hope. Only one day early, during our first meeting on the streets of Passo Fundo, the police and the local fiscalization officers confiscated his products. This was just one of the several setbacks and disappointments Souleymane experienced during his migration. These unique incidents on the micro-level shaped his overall negative experience in migrating to Brazil and need to be considered for the understanding of his feeling of disillusion. It would be too easy to relate it solely to unrealistic expectations and his idea of Brazil as a new 'El Dorado.' Souleymane undergoes what Haugen (2012) called a second state of immobility, which is both spatial and existential. He lacks the means to move elsewhere and cannot go back to Senegal 'emptyhanded.' "It is better to die here," he said frustrated.

Maguette, a 27-year-old Senegalese unmarried man from Mbour, whom I met for the first time in December 2017 in Passo Fundo, is another example of the failure of hope, but also one for its reorientation. After finishing secondary education, he wanted to study abroad, get to know other cultures and find a better life. He desired to go to Canada, but the migration broker, who he entrusted with his visa request, did not perform as wanted. Maguette wanted to leave Senegal anyway and the broker told him about Brazil and referred him to another one, who could organize the travel. Maguette decided to try his luck and seek a better life in Brazil and paid around 3.000 US\$ for the journey, which took him through Ecuador, Peru, and almost the complete extent of Brazil. However, things did not turn out to be as desired:

The hope we had was to come here to Brazil, get a good job and help our families in Senegal. There are some who were able to get a good job, some managed to get along quite well. Some not. For others, things are even worse. So, for me, the hope that I had, what I expected of Brazil, I have not found it yet. I spend some time here, but if I look, if I really look [at it], I think it is a waste of time....It is very different, because in reality we did not find what we hoped for. That is the reason why we have other 
things on our minds, like to get out of here. The things we have hoped for, so far we have not seen anything. (Maguette, April 2019)

Over time, he became increasingly disillusioned with his stay in Brazil and developed an urgent desire to leave the country and seek his fortune elsewhere. Maguette's story is one of hope, opportunities, risk-taking, disillusion and renewed hope. Contrary to Souleymane, he reorientated his hope after being disappointed by Brazil, which lies now on the movement to Canada. Some migrants had more success in Brazil than they thought, but many share the feeling of disillusion and disappointment. According to Maguette, the lack of concrete information and false assumptions were responsible for the growth of Senegalese immigration in Brazil:

In 2013, 2014, 2015, 2016, the flow of emigration from Senegal to Brazil began. But that also happened because many of them were wrong. Many of them came here without one, without any clue. They just said that they want to leave Senegal.

While this may be true in some cases, many migrants, especially the ones with network contacts in Brazil, had a more accurate image, but could not foresee the economic crisis. Most Senegalese migrants arrived at a time marking the transition from economic growth to recession, and the negative impact of the economic crisis on the formal labour market was felt by immigrant employees only in 2016 (Cavalcanti, de Oliveira, Araujo, \& Tonhati, 2017, p. 78). Several of my interviewees, who arrived between 2010 and 2015 had first benefited from the demand for labour, but later lost their job due to the crisis. Therefore, it seems more accurate to argue that both the unpredictability of the future and ill-informed expectations are reasons for the disillusion and the feeling of suffering from unexpected economic difficulties.

\section{Onward Migration Intentions: Circumstances, Potentiality and Risk-Taking/Strategies}

Without doubt, economic factors play an important role in the development of intentions to leave Brazil and move to another country. But not all interviewees, who expressed theses intentions, experienced economic difficulties in Brazil. Intentions of both 'successful' and 'unsuccessful' migrants are shaped by social imaginaries that divide the world hierarchically (Belloni, 2020). North America and Europe are at the top of this hierarchy of destination countries. Migration to the USA is regarded as better and more desirable as to Brazil, which, in the words of some migrants, is almost the same as Senegal. These hierarchies shape the imagination that things will be even better in another country. Maguette, who already was quoted above, is one of the migrants who was not able to meet his aspirations in
Brazil. He expresses his desires to move to Canada:

My plans now? To leave Brazil! And go to Canada or some other country. I saw that in Canada you have job opportunities. You have study opportunities. If I get a visa tomorrow, I will leave tomorrow....Today I have the experience. I am telling you that I want to go to Canada. But what I suffered here, I will not suffer there....I am going to succeed faster...because here in Brazil I gained a great experience. I have seen a lot. I have heard a lot. I have already attended several things. Understood? I already have that potential, you know. (Maguette, April 2019)

During my last visit to Passo Fundo in April 2019, Maguette was searching for a language school in Canada. The enrolment in a language course, together with his enrolment at the University of Passo Fundo, would strengthen his claim for a visa. He was in constant contact with a Brazilian friend, whose acquaintance he had made and who was now living in Canada, seeking for information about schools and bureaucratic processes. Several times he stated that the ability to go there, or more precisely the ability to leave a Brazilian airport and travel there, is what counts. He was convinced that once he arrives in Canada, he will be able to get around, for instance by applying for asylum. Due to the expected opportunities structures in Canada, it is worth trying, despite the risk of deportation. His willingness to take great risks is strengthen by the assumption that his experiences in Brazil will help him succeed faster and the feeling that he has nothing to lose in Brazil. Despite his negative experience of migration, he does not fear that migrating to Canada could be unsuccessful as well. Maguette shows a renewed hope that is postponed to the new future and simultaneously spatiality reoriented. The projection of his hope elsewhere allows him to remain optimistic about his future, even though his ability to move there is clearly restricted and the fulfilment of his desire remains extremely uncertain. Desire for onward migration is widespread among the Senegalese migrants I met in Brazil, but their ability to do so is limited. Once again, they find themselves waiting for favourable circumstances, for opportunities to emerge that allow them to pursue their hope elsewhere.

While the desire to move onward does not necessarily depend on the economic situation of the migrant in Brazil, the strategies of successful or unsuccessful migrants differ strongly. Success does not only refer to the financial situation of the migrant, but more in general to a feeling of accomplishment and the meeting of his or her aspirations. In contrast to Maguette, migrants with a stronger sense of achievement try to minimize the risks of onward migration. Seydou, 32-year-old and married to a Brazilian, owns a business in Caxias do Sul. He wants to start a family and dreams about raising his children in an anglophone country, like the USA or England, indicating his hierarchies of destinations: 
I want to raise my family in a country where English is the official language. In other words, the United States, England, Australia, New Zealand, Ireland. No matter which one of these countries, I am willing to go. And I am also thinking that by 2020 I will leave Brazil....But it is a challenge to leave the work that I have here, the income that I have here, and go to another country and start from scratch. It is a very big challenge. But it is a challenge that I want to overcome....Because after I came here, I already have a way of understanding [things]. Nowadays I am not going to get up and go to a country out of nowhere. For example, if I want to continue and live in the United States, I will make a point of going there for at least 20 days to observe before I move [definitely]....I would not do it the same way as I did here, because I know the difficulties that exist. (Seydou, March 2019)

Like Maguette, Seydou mentions the importance of experience for his plans of onward migration, but in his case, experiences affect migration decision-making in a different way. He does not want to take risks. Migration experiences together with the concern of starting all over again in a new country and undergo the same difficulties again that he had successfully overcome in Brazil, lead to a different approach to further movements. A temporary movement for exploration purposes is a strategy to minimize risks of disillusion and failure, and was also mentioned by other migrants, especially the ones who are doing relatively well in Brazil. By contrast, migrants who have nothing to lose or no other obligations, for example a family in Brazil, often would not hesitate to move again without precautions to another country. While Seydou's aspirations for onward migration are well developed, he still leaves room for a change of plans. He did not completely lose societal hope in Brazil. The recovery of the economy and better foreign exchange rate of the Real would be arguments for staying in Brazil. His social hope is not solely connected to spatial movement, but also persists in its temporary form.

\section{Conclusion}

Migration opportunities for Senegalese are becoming increasingly rare and the ability to move internationally is limited in times of restricted mobility regimes. This impacts the choice of Brazil as a destination in two ways. First, the country is seen as an alternative for emigration, especially in the case of unsuccessful attempts to emigrate elsewhere. International migration as an important element of social hope in Senegal is redirected to Brazil. Positive images of the country based, among others, on its economic growth until 2014, the realization of global events, and accounts of successful migrants contributed to this redirection. Secondly, in the absence or scarcity of migration opportunities, migration brokers influence decisions by mediating and facilitating movements and even by actively encouraging migrants to try their luck in Brazil. Migration brokers can be understood as important repositories of hope, who allow aspiring migrants to develop or maintain social hope. In consideration of widespread migration aspirations in Senegal, prospective migrants need to grasp an opportunity when it appears. This sudden emergence of opportunities results from contacts, networking and processes of mediation on the micro-level.

In this context of limited opportunities, uncertainties and risks of migration are often less strongly weighted and, as the results show, played a minor or no role in the context of emigration decisions in Senegal. Moreover, since migration from Senegal to Brazil is only a recent development, the knowledge and information about the country in Senegal are limited. A lack of information and ill-informed expectations often characterized the choice of Brazil as a destination and resulted not only in uncertainties, but also in feelings of disillusion experienced by Senegalese migrants in Brazil. In other cases, it was the unpredictability of the future in the face of the economic crisis that created uncertainties and shattered the hope of a better life in Brazil. The impact of uncertainties in onward migration intentions shows a more differentiated picture. Depending on the degree of satisfaction in Brazil, migrants' attitude regarding uncertainties changes and they adopt different strategies for onward migration. Migrants with a strong feeling of disillusion and disappointment are in general more willing to take risks than migrants with a higher degree of satisfaction and economic success in Brazil. In the cases of migrants who lost the belief that their situation in Brazil will change for the better, hope is connected again solely to spatial movement and, as before, with the decision to leave Senegal, uncertainties and risks are deliberately accepted and do not strongly affect the decision.

\section{Acknowledgments}

I would like to thank the anonymous reviewers and editors for their helpful feedback. My special gratitude goes to all my Senegalese informants, who gave me their trust and shared their experiences and histories with me. This research was supported by the FCT, the Portuguese Foundation for Science and Technology (grant number PD/BD/128347/2017) and the DiasporaLink Program financed by the Research Executive Agency (grant number 645471).

\section{Conflict of Interests}

The author declares no conflict of interest.

\section{References}

Adepoju, A., Van Noorloos, F., \& Zoomers, A. (2009). Europe's migration agreements with migrantsending countries in the Global South: A critical review. International Migration, 48(3), 42-75. 
Alpes, M. J. (2012). Bushfalling at all cost: The economy of migratory knowledge in Anglophone Cameroon. African Diaspora, 5, 90-115.

Alpes, M. J. (2017). Why aspiring migrants trust migration brokers: The moral economy of departure in Anglophone Cameroon. Africa, 87(2), 304-321.

Appadurai, A. (1996). Modernity at large: Cultural dimensions of globalization. Minneapolis, MN: University of Minnesota Press.

Belghazi, T., \& Moudden, A. (2016). Ihbat: Disillusionment and the Arab Spring in Morocco. The Journal of North African Studies, 21(1), 37-49.

Belloni, M. (2020). Cosmologies and migration: On worldviews and their influence on mobility and immobility. Identities. https://doi.org/10.1080/1070289X. 2020.1748357

Bloch, E. (1986). The principle of hope. Cambridge, MA: MIT Press.

BRASIL. (2010). A cooperação técnica do Brasil para a África-2010. [Brazil's technical cooperation for Africa-2010]. Brasília: Agência Brasileira de Cooperação, Ministério das Relações Exteriores.

BRASIL. (2019). Portaria interministerial no 10, de 5 de Dezembro de 2019 [Interministerial ordinance no. 10, December 5, 2019]. Brasília: Ministro de Estado da Justiça e Segurança Pública, Ministro de Estado das Relações Exteriores.

BRASIL. (2020). Comitê nacional para os refugiados [National committee for refugees]. Portal de dados do Ministério da Justiça. Retrieved from http:// dados.mj.gov.br/dataset/comite-nacional-para-osrefugiados

Carling, J. (2002). Migration in the age of involuntary immobility: Theoretical reflections and Cape Verdean experiences. Journal of Ethnic and Migration Studies, 28(1), 5-42.

Carling, J. (2012). Collecting, analysing and presenting migration histories. In C. Vargas-Silva (Ed.), Handbook of research methods in migration (pp. 137-162). Cheltenham: Edward Elgar Publishing Limited.

Carling, J., \& Haugen, H. Ø. (2020). Circumstantial migration: How Gambian journeys to China enrich migration theory. Journal of Ethnic and Migration Studies. https://doi.org/10.1080/1369183X.2020.1739385

Cavalcanti, L., de Oliveira, A. T., Araujo, D., \& Tonhati, T. (2017). A inserção dos imigrantes no mercado de trabalho brasileiro: Relatório anual 2017 [The insertion of immigrants in the Brazilian labour market: Annual report 2017]. Brasília: Observatório das Migrações Internacionais, Ministério do Trabalho e Conselho Nacional de Imigração \& Coordenação Geral de Imigração.

de Boeck, F. (2012). City on the move: How urban dwellers in Central Africa manage the siren's call of migration. In K. Graw \& S. Schielke (Eds.), The global horizon: Expectations of migration in Africa and the Middle East (pp. 59-85). Leuven: Leuven University Press.
Fiedler, A. (2020). From being aware to going there: On the awareness and decision-making of (prospective) migrants. Mass Communication and Society, 23(3), 356-377.

Finotelli, C., \& Sciortino, G. (2013). Through the gates of the fortress: European visa policies and the limits of immigration control. Perspectives on European Politics and Society, 14(1), 80-101.

Freier, L. F., \& Holloway, K. (2018). The impact of tourist visas on intercontinental south-south migration: Ecuador's policy of "open doors" as a quasiexperiment. International Migration Review, 53(4), 1171-1208.

Gaibazzi, P. (2015). The quest for luck: Fate, fortune, work and the unexpected among Gambian Soninke hustlers. Critical African Studies, 7(3), 227-242.

Glick Schiller, N., \& Salazar, N. B. (2013). Regimes of mobility across the globe. Journal of Ethnic and Migration Studies, 39(2), 183-200.

Graw, K. (2012). On the cause of migration: Being and nothingness in the African-European border zone. In K. Graw \& S. Schielke (Eds.), The global horizon: Expectations of migration in Africa and the Middle East (pp. 23-42). Leuven: Leuven University Press.

Graw, K., \& Schielke, S. (2012). Introduction: Reflections on migratory expectations in Africa and beyond. In $\mathrm{K}$. Graw \& S. Schielke (Eds.), The global horizon: Expectations of migration in Africa and the Middle East (pp. 7-22). Leuven: Leuven University Press.

Hage, G. (2003). Against paranoid nationalism: Searching for hope in a shrinking society. London: Pluto Press and Merlin.

Halfacree, K. H. (2004). A utopian imagination in migration's terra incognita? Acknowledging the noneconomic worlds of migration decision-making. Population, Space and Place, 10, 239-253.

Harris, J. R., \& Todaro, M. P. (1970). Migration, unemployment and development: A two-sector analysis. The American Economic Review, 60(1), 126-142.

Haug, S. (2008). Migration networks and migration decision-making. Journal of Ethnic and Migration Studies, 34(1), 585-605.

Haugen, H. Ф. (2012). Nigerians in China: A second state of immobility. International Migration, 50(2), 65-80.

Hernández-Carretero, M. (2017). Hope and uncertainty in Senegalese migration to Spain: Taking chances on emigration but not upon return. In N. Kleist \& D. Thorsen (Eds.), Hope and uncertainty in contemporary African migration (pp. 113-133). London and New York, NY: Routledge.

Kleist, N. (2017). Introduction: Studying hope and uncertainty in African migration. In N. Kleist \& D. Thorsen (Eds.), Hope and uncertainty in contemporary African migration (pp. 1-20). London and New York, NY: Routledge.

Lubkemann, S. C. (2017). The lack of liberty drove us there: Spatialized instantiations of hope and contested diasporan identity in the Liberian-American 
transnational field (1810-2010). In N. Kleist \& D. Thorsen (Eds.), Hope and uncertainty in contemporary African migration (pp. 76-93). London and New York, NY: Routledge.

Mar, P. (2005). Unsettling potentialities: Topographies of hope in transnational migration. Journal of Intercultural Studies, 26(4), 361-368.

Mbodji, M. (2008). Imaginaires et migrations: Le cas du Sénégal [Imaginaries and migration: The case of Senegal]. In M.-C. Diop (Ed.), Le Sénégal des migrations: Mobilités, identités et societés [The Senegal of migration: Mobilities, identities and societies]. Paris: Karthla.

Minvielle, R. (2015). L'Amérique du Sud ou l'émergence d'un nouveau théâtre des migrations africaines. [South America or the emergence of a new theatre of African migration]. Afrique et Développement, 40(1), 19-39.

Prothmann, S. (2018). Migration, masculinity and social class: Insights from Pikine, Senegal. International Migration, 56(4), 96-108.

Salazar, N. B. (2011). The power of imagination in transnational mobilities. Identities: Global Studies in Culture and Power, 18(6), 576-598.

Schapendonk, J. (2012). Turbulent trajectories: African migrants on their way to the European Union. Societies, 2, 27-41.

Snel, E., Engbersen, G., \& Faber, M. (2016). From bridge- heads to gate closer: How migrant networks contribute to declining migration from Morocco to the Netherlands. In O. Bakewell, G. Engbersen, M. L. Fonseca, \& C. Horst (Eds.), Beyond networks: Feedback in international migration (pp. 134-155). Basingstoke: Palgrave Macmillian.

Vammen, I. M. S. (2017). Sticking to God: Brokers of hope in Senegalese migration to Argentina. In N. Kleist \& D. Thorsen (Eds.), Hope and uncertainty in contemporary African migration (pp. 40-57). London and New York, NY: Routledge.

Vammen, I. M. S. (2019). New contested borderlands: Senegalese migrants en route to Argentina. Comparative Migration Studies, 7(8), 1-17. https://doi.org/ 10.1186/s40878-018-0109-z

Vigh, H. (2008). Crisis and chronicity: Anthropological perspectives on continuous conflict and decline. Ethnos: Journal of Anthropology, 73(1), 5-24.

Vigh, H. (2009). Wayward migration: On imagined futures and technological voids. Ethnos: Journal of Anthropology, 74(1), 91-109.

Vives, L. (2017). The European Union-West African sea border: Anti-immigration strategies and territoriality. European Urban and Regional Studies, 24(2), 209-224.

Williams, A. M., \& Baláž, V. (2012). Migration, risk, and uncertainty: Theoretical perspectives. Population, Space and Place, 18, 167-180.

\section{About the Author}

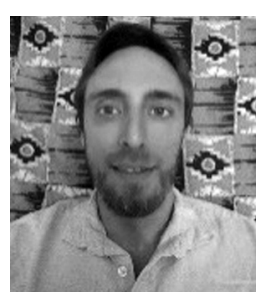

Philipp Roman Jung is currently a PhD student in Migration Studies at the Institute of Geography and Spatial Planning (IGOT), University of Lisbon. He holds a master's degree in African Studies from ISCTE-University Institute of Lisbon, and a BA in African Development Studies in Geography from the University of Bayreuth. For his doctoral thesis he studies the mobility trajectories of Senegalese migrants in Brazil with a focus on migrants' agency and the dynamic nature of migration aspirations and decisions. Former research addressed the migration from Senegal to Cape Verde and the reverse flow of remittances. 